\title{
Dialogue of Cultures: Challenges of Globalization
}

\author{
Nur Kirabaev ${ }^{1, *}$
}

\author{
${ }^{1}$ Department of History of Philosophy, Faculty of Humanities and Social Sciences, Peoples' Friendship University of \\ Russia, 6 Miklukho-Maklaya Street, Moscow 117198, Russia \\ *Corresponding author. Email: kirabaev@gmail.com
}

\begin{abstract}
The article is dedicated to the consideration of Islamic civilization in the context of the dialogue of contemporary world's cultures caused by globalization processes. Islamic civilization is presented as the interaction of different cultures, historically formed on universal underlying values and moral norms. The author deduces stereotypes of consideration of Islam and threats "coming from it" existing in modern-day humanities and social sciences. The researcher refers to them theoretical attempts to describe the realities of the Muslim world in terms of the Christian tradition, as well as related to the particular ideological attitude and methodology of so-called Eurocentrism. Conclusions are made about the role and significance of Islamic civilization for the preservation of sustainable development of countries within the global world.
\end{abstract}

Keywords: Islam, Islamic civilization, Arab Muslim culture, cultural stereotypes, history of medieval Arab

\section{Muslim philosophy}

\section{INTRODUCTION}

Religion is a cultural system, and culture is receiving more and more attention in world politics. We can state that one of the manifestations of the global crisis is the aggravation of religious and ethnic conflicts. We need response to question: how to correlate globalization, which is oriented to the values of unity with the domination of national and state forms of management and the dominance of differentiation on cultural and religious practices, identification by a some number of features, as well as pluralism of opinion in society? Does globalization imply orientation to conventional cultural and civilizational values and equate it with westernization?

If we consider the adaptation of new technologies and ideas to regional conditions as a descriptive process of globalization, then localization and individualization may become dominant trends. Globalization under such circumstances no longer forms an abstract single cultural and educational space, and its emergence is associated with far more than one source. It is about the contribution of national cultures to the global culture. Moreover, globalization is accompanied by the socalled regionalization, i.e., the increasing importance of subcultures (e.g., Latin American, Southeast Asian,

*Fund: The reported study was funded by RFBR, project number 20-011-00045 A "The Influence of Ethnocultural, Religious, Communicative, Educational and Migration Factors on the Development of the Contemporary Tourism Industry: SocioPhilosophical Inquiry." etc.).

However, pointing globalization to the values of unity and the communality can lead to division and a new type of inequality, i.e., there is a gap between the producing and consuming countries. It is also essential to bear in mind that, within countries themselves, there are fractures among the social groups that participate in globalization and those that passively consume its "fruits." Thus, in the context of globalization, culture, and education, a researcher must assume that globalization cannot become an integrated whole through convergence based on a common set of cultural values. The following question must be answered: what holds these different parts of the whole together and what gives them coherence. That is, how to preserve the value of pluralism as the world seeks a single social space.

\section{ISSUES OF UNDERSTANDING THE "CROSSROAD OF CULTURES"}

Cultural values are naturally changing, but changes in culture are not reflections of social change, although there is an interaction between them. Some social scientists argue that changes in the dominant socialization procedure, including contemporary values and norms, are self-sufficient to cause dynamic changes in society. At the same time, it should be taken into account that globalization has destroyed the boundaries of the so-called first, second, and, consequently, third worlds of the development era. 
At present, we know that civilizations and local cultures are increasingly crucial for peoples and countries in the search for new national and cultural identities. It is impossible to work seriously in nonEuropean cultures and civilizations without knowing them from the inside. Without knowledge of the fundamental bases of culture, as well as without understanding the peculiarities of spiritual life, we will not be able to understand what was known in the West as the "third world," even if we are familiar with the structure of the world market and know the trends of economic development.

Nowadays, the entire Islamic civilization is considered in Europe as a potential source of conflicts in the modern world. Is the dialogue between East and West possible under such conditions? The answer to this question is to find out the reasons for considering the Islamic civilization as a threat to the modern world, a source of contradictions between countries. Let us try to outline the contours and context of the problem in terms of understanding Islamic civilization.

Some of the significant figures claimed that those who know history know the future. Indeed, our past does determine the vector of development in many ways. Contribution of Islamic civilization in world history has been significant. Sure, it continues to have a noticeable impact on various areas of life in different countries. Today there are more than 1.5 billion Muslims worldwide, and 57 countries with a population of about 1.5 billion are members of the Organization of Islamic Cooperation (OIC). There are numerous Muslim diasporas in Europe. Thus, their number increased from 29.6 million in 1990 to 44.1 million in 2010. The share of the population professing Islam has increased from $4.1 \%$ to $6 \%$, an increase of almost $50 \%$. According to rough projections, the proportion of the Islamic population rises from $4.1 \%$ to $6 \%$ by $2030.8 \%$ of the people of Western Europe will be Muslims in 2030, and every fourth by 2100 .

As for the Muslim diaspora in the USA, there are no official statistics, because according to the laws of the country, religious affiliation is not recorded in the national census, which occurs every ten years. That is why the number of adherents of Islam in the USA is estimated approximately. According to the report of the Statistical Association of American Religions on changes in the religious composition of the U.S. population, for ten years $(2000-2010)$, there has been an increase in the number of Americans professing Islam. Thus, from 2000 to 2010 , the number of people who identify themselves as Muslims increased from 1 million to 2.6 million. According to the Pew Research Center (PRC) forecast, the number of U.S. citizens professing Islam will increase from 3.3 million to 8.1 million by 2050 , making about $2.1 \%$ of the total population. Russia has a Muslim population of
$21,513,046$ (15\% of the population). In Turkey, $68,963,953$ people are Muslims or $99 \%$ of the population.

Traditionally, the notion of civilization is associated with a country or continent, such as Europe, China, India, etc. However, Islamic civilization is not causally linked to any geographical location but covers the entire modern continental and subcontinental world. Thus, the peoples and countries that identify themselves as an integral part of the Islamic civilization are consolidated by the specificity of what is called Islam and Islamic civilization. It unites peoples of different ethnic groups, cultures, languages, and traditions from Syria to Malaysia, from Tatarstan to South Africa. It is thus challenging to consider a single historical community of fates of these peoples. Islam is a unity in diversity. We should discuss a special kind of solidarity, based not only on faith in Allah but also on a shared Worldview. However, such civilizational solidarity is not monolithic and non-conflictual. It does not exist in a pure form but is the result of cross-cultural interaction in the broad sense. The Islamic civilization can instead be considered as an epiphenomenon, i.e., a result of intercultural communication of different civilizations. Its peculiarity is close interrelation with religion, which is a way of life, a system of values, social, political, and economic institutions. We may call Islam one of the most viable world religions, dynamically adapting to the peculiarities of different peoples' traditions and cultures. The increase in the number of Muslims in the modern world is more connected with the attraction of new adherents, "enchanted" by the attractiveness and simplicity of Islamic religious practices. At the same time, in the broad sense, Islam has brought a large number of problems to the modern world, both at the level of interstate and interreligious relations and at the level of international political and economic life. Since 1967, media and researchers used frequently the term "Islamic factor". After the 1979 Iranian Revolution, the threat to the world order is associated with Islam. The Western countries started to correlate Islam with a sense of anxiety, and with extremism and terrorism in the 1980s. After S. Huntington's 1993 article "The Clash of Civilizations", the entire Islamic civilization began to be considered as a potential source of conflicts in the modern world.

At present, it is rather obvious that in assessing Islam, stereotypes play a significant role. They arise as some researchers attempt to describe the realities of the Muslim world using terms of the Christian tradition, as well as those related to the particular ideological and cognitive attitude and methodology of Eurocentrism. It is accepted that modernity is the totality of existence, but as history shows, it is not so. The study of the state of Muslim culture shows that not only is there not enough knowledge about it, but its image is often much distorted. Speaking about the problem of stereotypes, 
we should note that up to the present day, false culturalphilosophical and political-ideological stereotypes prevail in various research and the consciousness of the public. Suffice to point out the widespread use of Islamic fundamentalism in the media, the content of which is interpreted quite broadly and arbitrarily understood rather as religious extremism. It is, therefore, necessary to distinguish between fundamentalism and extremism. In general, stereotypes are the result of either insufficient knowledge or an inadequate methodology or are formed per the ideological and socio-cultural attitudes of the cognizing subject. In Islam, as a rule, orthodoxy, theology, church ideology, etc. are sought by analogy with Christianity. However, these phenomena simply do not exist in Muslim culture. It is also improper to think about Islam and Islamic culture abstractly without taking into account that Islam and its culture in different historical epochs and different countries have their manifestation.

The politicization of what is commonly referred to as the Islamic factor began in the early 1970s after some Arab countries, primarily Saudi Arabia, imposed an oil embargo on the states supporting Israel in its war with Egypt in 1973, which led to the first energy crisis. The embargo period was short, but in the historical memory of Western countries, Islam and the Arab countries were considered responsible for the crisis. After the 1979 Islamic Revolution in Iran, the stereotype of the Islamic threat became the dominant topic in the media. After 1991, the military implementation of the liberal democracy model in the Middle East led to irreversible and severe consequences in Afghanistan, Iraq, Libya, Syria, and Yemen. Mass migration from the Middle East and Africa has led, among other things, to a significant strengthening of the European sense of fear and threat from Islam.

Islam, as well as Christianity, belongs to the world religions. Accordingly, it carries attitudes on the universal vision of the world. Obviously, since the publication of S. Huntington's article The Clash of Civilizations, the idea of a clash of Western and Muslim civilizations claiming universalism has been asserted. We consider this position, to put it mildly, incorrect, given the fact that Islamic and Western European Christian civilizations have been neighboring within a single Mediterranean civilization throughout many centuries of history. Thus, it seems that the main difference between Islam and the West is related to the difference in value systems and norms. Each of them has its understanding of the world.

Moreover, if the Islamic worldview bases on certain religious principles, the European one is notable for its secularity. Only on this level, we may speak about the dialogue of two Universalist Worldviews. The recognition of cultural and religious pluralism can be the dialogue's basis. Thus, the matter may concern the search and establishment of cross-cultural interaction, including moral grounds. At the same time, it is vital to remember that the politicization of Universalist worldviews is the basis for considering and asserting the idea of clash or conflict of Islamic and Western European civilizations. The proposed approach to the search for a dialogue of Islam in the East-West context requires knowledge and understanding of the shared history underlying the formation and development of these civilizations in the Mediterranean area.

Furthermore, the matter is that Islam and Christianity belong to the Abrahamic religious tradition, and that the ancient culture is an integral part of these civilizations. It is crucial to stress that for the Arab East, Aristotle has always been the First Teacher. The main differences in the historical and cultural development, especially after the Renaissance, can probably be found in the ratio of secular and religious movements. Classical Islamic culture preserved the balance between religion and secularism. That balance defined the primary worldview and value principles.

\section{Classical Arab Muslim AND CONTEMPORARY ISLAMIC CULTURES}

How can we compare classic Arab Muslim culture, which was open to interactions, and the modern Islamic one, which, if not opposed, is not welcoming recent inter-civilizational dialogue? The values of Islamic culture and those of any other civilizations are determined mainly by fundamental values that constitute the basis of value consciousness in their integrity. Those of Islamic culture were primarily determined by the peculiarities of the formation and development of the Arab Caliphate. The traits of classical Islamic culture, as of its paradigms in general, are determined mainly by the fact that it was formed as an integral part of a unique Mediterranean culture and civilization, and by the fact that it preserved and multiplied the cultural, scientific and philosophical traditions of antiquity, as well as developed the humanistic nature of Mediterranean culture but in other historical conditions. It is not surprising that in the Arab East, antique heritage was the source and integral part of the Islamic world's culture.

The development of Islamic civilization is closely connected with the emergence and strengthening of Islam and the Caliphate, whose vast space was a center of interaction and mutual enrichment of various cultural and religious traditions. The Islamic Golden Age came in the $9^{\text {th }}-12^{\text {th }}$ centuries, when Islam started to define the level of global culture - both spiritual and material. One of the crucial traits of classical Islamic culture is that its main structural elements are not so much scientific (as was the case in Western European thought) but the value and ideological processes, determining the nature of knowledge, interpretation, 
and scope of adequate understanding of the epistemological map of the world. These processes have a conventional paradigm based on a specific set of assessments and perceptions of the limits of human existence in the world, the nature, and connection with the cosmos, reflected in the Islamic world. It was in the problem field of knowledge (based on the ideal of knowledge in Islam) that intellectuals of the Islamic Middle Ages solved each problem separately - be it cultural and political issues, ethics and aesthetics, philosophy and law. All major philosophical and sociopolitical trends of the Muslim Middle Ages, without limiting themselves to one specific subject of knowledge, acted as political, or philosophical, or legal, or ethical theories, etc. related to political problems.

The peculiarities of the ideal of knowledge in Islamic culture was defined by Sharia, according to which faith and mind should not oppose each other but rather mutually enrich in the field of knowledge. Thus, we can say that medieval Islamic culture is knowledgecentered. For example, the work of the famous medieval thinker al-Ghazali (1058-1111) The Revival of Religious Sciences (Ihya' Ulum al-Din) can be simultaneously considered philosophical, legal, religious, linguistic, and cultural, i.e., interdisciplinary in the modern sense [2]. It is not without reason that the famous philosopher Averroes (1126-1198) spoke about al-Ghazali: “... he was an Ash'arite with the Ash'arites, a Sufi with the Sufis and a philosopher with the philosophers" [3]. Many representatives of Kalam wrote not only on religion but also on philosophy and natural science. The matter here is not in the weak differentiation of sciences, but in the proper spiritual attitude of Islamic culture, based on the famous statement attributed to the prophet Muhammad: "Seek knowledge even in China."

In medieval Arab Muslim civilization, as American orientalist Franz Rosenthal stresses in his Knowledge Triumphant [4], "knowledge" has acquired such significance that there is no equal in other civilizations. The "knowledge" is both secular and religious. The nature of the value orientation of the educated part of the medieval Islamic society can be judged from Adab literature. Adibs embody the image of cultural and educated people. Adab, a set of norms of education and politeness, assumed the knowledge of both secular and religious sciences, in particular philosophy, astronomy, mathematics, and a specific model of behavior.

Crucial for understanding the paradigm of Islamic culture are such features of Islam as the absence of the institution of the church and, consequently, the lack of church ideology; the recognition of the law-making role only for God and, hence, the absence of orthodoxy and heresy in the Christian sense; religious and legal pluralism within a single Islamic worldview. In describing the paradigm of Islamic culture and civilization, it seems necessary to identify at least two dominant components: Islam and Hellenism. Throughout its history, Islamic culture has shown and demonstrated both its "Western face," as it contains elements of Judaism, Christianity and Hellenism, and the "Eastern face," as it departs from the essence of these components. By taking the latter into account, it is possible to understand the humanistic component linked to the attempt to make human beings more humane and to contribute to the discovery of their greatness.

We are discussing three aspects of humanism in medieval Islamic culture:

- religious humanism, proclaiming man the supreme of divine creations;

- Adab humanism, the archetype of which is the 9th-century Adab, corresponding to the ideal of Humanitas, which is characteristic of 16thcentury Europe. That is, the idea of the development of physical, moral and mental capacities of an individual for the common good;

- Philosophical humanism, more conceptualized. Abū Hayyān al-Tawhīdī briefly expressed its essence: "Man has become a problem for man" [5].

While paying tribute to and recognizing the existence of universal traits and principles of humanism, we should also mention that every culture and civilization in its prime is developing its humanism model. It is also true that, even within the framework of Islamic culture, humanism lies in various forms. In the East, this phenomenon first became known during the reign of Khosrow I Anushirvan and was introduced by Barzuyeh, Paul the Persian, and others. The humanism that came to life under the influence of Hellenistic Gnosticism, hermeticism and Neoplatonism followed. That humanist quest focused on the theme of the "perfect man" and was represented by the names of Ibn Arabi, Abd al-Karīm al-Jīlī (1365-1417), Al-Hallaj (857-922) and Yahya ibn Habash Suhrawardī (11541191). At least, but not last, humanism, which emphasizes the greatness of the human mind (as in the hadith, attributing to the prophet Muhammad the words "Whoever knows God knows himself" and "The first thing created by God is the mind"), is found in the work of Muhammad ibn Zakariya al-Razi (850-925), who rejected Revelation and affirmed the autonomy of the human mind in the spirit of European Enlightenment.

The ambivalence of Islamic culture, based on the principles of Sharia and the historical practice of the Caliphate, suggests its consideration in terms of both earthly and heavenly, as well as esoteric and exoteric. Considering the significant role of Sharia in the world and the predominance of worldly attitudes in human 
behavior and thought, we should note that Islamic culture has preserved and maintains a stable connection between the ideas of space and ethics. This fact allowed us at one time to consider "foreign science" (philosophy, oriented at the ancient tradition) as an integral part of our own culture, and allows us to leave the doors open for modern European science and culture.

Considering esoteric versus exoteric relations in the issue of reason-faith, it is necessary to note the nature of their complementarity. The analysis of the theological and philosophical levels of solving the problem of the correlation of reason and the institutions of faith shows the following. Despite the divergence in positions of different thinkers, they agree that in their totality they followed the esoteric tradition associated with the priority of reason. In so doing, they paved the way for Sufi esoteric knowledge and its intellectual attempt to harmonize Sharia and Tariqa as the justification of its approach to the problem. Sufism did not regard the relation between reason and faith as "the very essence of the problem" but included it in the overall system of the connections among the Spiritual Stations: the Law, the Path, and the Inner Truth (Sharia, Tariqa, Haqiqa). At the same time, the Sharia, Tariqa, Haqiqa system organized a "logical form" of action of a cognizing subject in search of his Absolute, thus contributing to the appearance of many variations, one of which is the teaching of al-Ghazali. Realizing that Sufism is a historical and holistic phenomenon, we believe it is crucial to study it, taking into account the archetypes of the Sufi culture.

\section{CONCLUSION}

The philosophical analysis of Muslim culture requires identifying a stable paradigm and changes in the course of historical development. It is essential to consider this when analyzing concepts on the so-called reform or modernization of Islam. As a rule, the attempts made so far by the West to shape Islamic development have failed because the traditional foundations that represent the spirit of Islamic culture have been accepted as something that can historically be overcome. Meanwhile, social, historical, and political realities inherently show that understanding of traditional and modern essence is tightly related to the foundations of political and legal culture of Islam and the dominant ideological and cultural movements within the framework of developing Islam. The analysis of classical government theories in Islamic political thought, represented by such authors as al-Mawardi (d. 1058), al-Juwayni (d. 1085), al-Ghazali, clearly shows that the principles of Sharia did not interfere with the historical realities of the Caliphate and relied more on historical precedents [6]. The constant component of these concepts is the doctrine that the state is only a conductor of the Sharia principles. However, the question is who has the real political power - how are power and authority understood, what the consolidating component is, and moral and spiritual basis of a Muslim civil society. The idea of the unity of religion and state is based on not only a sense of religious solidarity but also on the need to understand that Islam is expected to establish equality and justice in social, political, and economic relations. The recognition of the fact that Islam is a way of life and a specific type of modern world outlook makes it possible to understand the idea of an Islamic state by its very essence.

\section{References}

[1] Eurasian Idea and Modernity. Ed. N.S. Kirabaev. - M.: RUDN 2002.

[2] Al-Ghazali. The Revival of Religious Sciences (Ihya' Ulum alDin). - Cairo, without year. - Vol. 1-4.

[3] Averroes. Decisive Treatise Determining the Nature of the Connection Between Religion and Philosophy // Classics of Arab Muslim Philosophy. - N.Y.: Edwin Mellen Press, 1999. P. 619-647.

[4] Rosenthal F. Knowledge Triumphant: The Concept of Knowledge in Medieval Islam / F. Rosenthal. - M.: Nauka, 1978.

[5] Sagadeyev, A. Humanistic ideals of the Islamic Middle Ages / A. Sagadeyev // Values in Islamic Culture and the Experience of History. Russian Philosophical Studies, I. Ed. by N. Kirabaev, Y. Pochta. - Washington, 2002. - P. 165-198.

[6] Kirabaev, N. The Political and Legal Culture of Medieval Islam N. Kirabaev // Values in Islamic Culture and the Experience of History. Russian Philosophical Studies, I. Ed. by N. Kirabaev, Y. Pochta. - Washington, 2002. - P. 135-164. 